\title{
An Investigation of the Dynamic Effect of Foreign Direct Investment (FDI) and Interest Rates on GDP in South Africa
}

\author{
Thomas Habanabakize, Daniel F Meyer \\ North-West University, South Africa \\ tomhaban12@gmail.com, Daniel.meyer@nwu.ac.za
}

\begin{abstract}
Economic growth in South Africa has been in the "doldrums" for the past decade. If well managed, foreign direct investment (FDI) and repo rate (interest rate) could have a positive impact and assist in rapid economic growth so urgently needed in South Africa. FDI has been a driving force for growth in many developing economies. Not enough has been done to attract FDI in South Africa. The country has enormous ability and capacity to attract FDI inflows and to have the advantages from it. A quantitative research approach was used to analyse the association amongst the variables which include FDI, GDP and repo rate in the South African economy. The South African Reserve Bank database was used and the period analysed is from 2000 to 2016. Statistical and econometric methods such as correlation analysis, unit root tests, ARDL Bounds test for cointegration, an error correction model (ECM), and the Granger causality tests were used. Subsequently, after the econometric model was estimated, findings indicated the existence of a long-run relationship between the three variables. While, a significant positive relationship exists between FDI and GDP, a negative long-run relationship was found between GDP and repo rate and interestingly a nonsignificant relationship between repo rate and FDI. In the short run, the positive effect of FDI on GDP is minimal whilst a significant and positive relationship exists between GDP and repo rate. The results did also show some limitations in the results, with regards to FDI and repo rate that there is no significant relationship between the variables, meaning that repo rate does not have an impact on FDIs. Although some long-run evidence was found of FDI playing a role in economic growth in South Africa, such impact is limited. Also very interesting is that the repo rate and FDI do not have a statistically significant relationship. This could be due to the rising risks associated with investments in the country. In conclusion, there are many variables which could have a positive impact on the attraction of FDIs and such factors will be explored further in future studies.
\end{abstract}

Keywords: Foreign direct investment (FDI), Gross Domestic Product (GDP), Interest rates (repo rate), South Africa

\section{Introduction}

South Africa is going through difficult internal economic conditions, with a depreciating currency, relatively high interest rates and political instability. All of these issues are affecting economic growth which is below 1.0\% (Dornbusch et al., 2011; Lings, 2017; SARB, 2018). As illustrated in Figure 1, growth in South Africa has been unstable and fluctuated between recoveries and recessions from 1995 to 2015 (World Bank, 2016). Economic growth in South Africa is expected to be above 1.0 percent for 2018, but the first quarter growth was -2.2 percent (Stats SA, 2018). Foreign direct investment (FDI) is universally acknowledged as beneficial to developing countries' economic growth (Samuel, 2013). But are economic growth and interest rates important to attract FDI? Continuous low level of economic growth not only affects the South Africa economy, but also affects all its citizens (Harmse, 2006). If South Africa continues to have low levels of economic growth, it will have an ongoing adverse effect on poverty, unemployment and inequality and development of the economy (Hogg, 2016). The global distribution of FDI is skewed, with 68 per cent of FDI is received by the top five percent of developed countries, while the bottom five percent which are all poor developing countries, only receive 1 percent of total FDI (Chakrabarti, 2003).

Regarding FDI flows to South Africa, the country re-entered the top 25 A.T Kearney FDI Confidence Index in 2017 (ATK Earney, 2017). For global investors to invest in an economy, the local investment environment must be stable with favourable conditions such a high return on investment and relatively high interest rates (Siddiqui, 2014). The results of the study provide a platform to examine the association amongst FDI, interest rate and GDP. Furthermore, the study lists possible policies which could be implemented in order to improve FDI inflow, with or without interest rates incentives. The purpose of the study is therefore to determine the relationship between FDI, interest rates and GDP in the case of South Africa. The theoretical objective includes 
definitions of concepts; to examine applicable theories; and to evaluate the relationship between FDI, interest rates and GDP. The empirical objective is to determine the statistical relationship between FDI, interest rates and GDP in South Africa.

Figure 1: South African Economic Growth Rates from 1995-2016

SOUTH AFRICA GDP GROWTH RATE

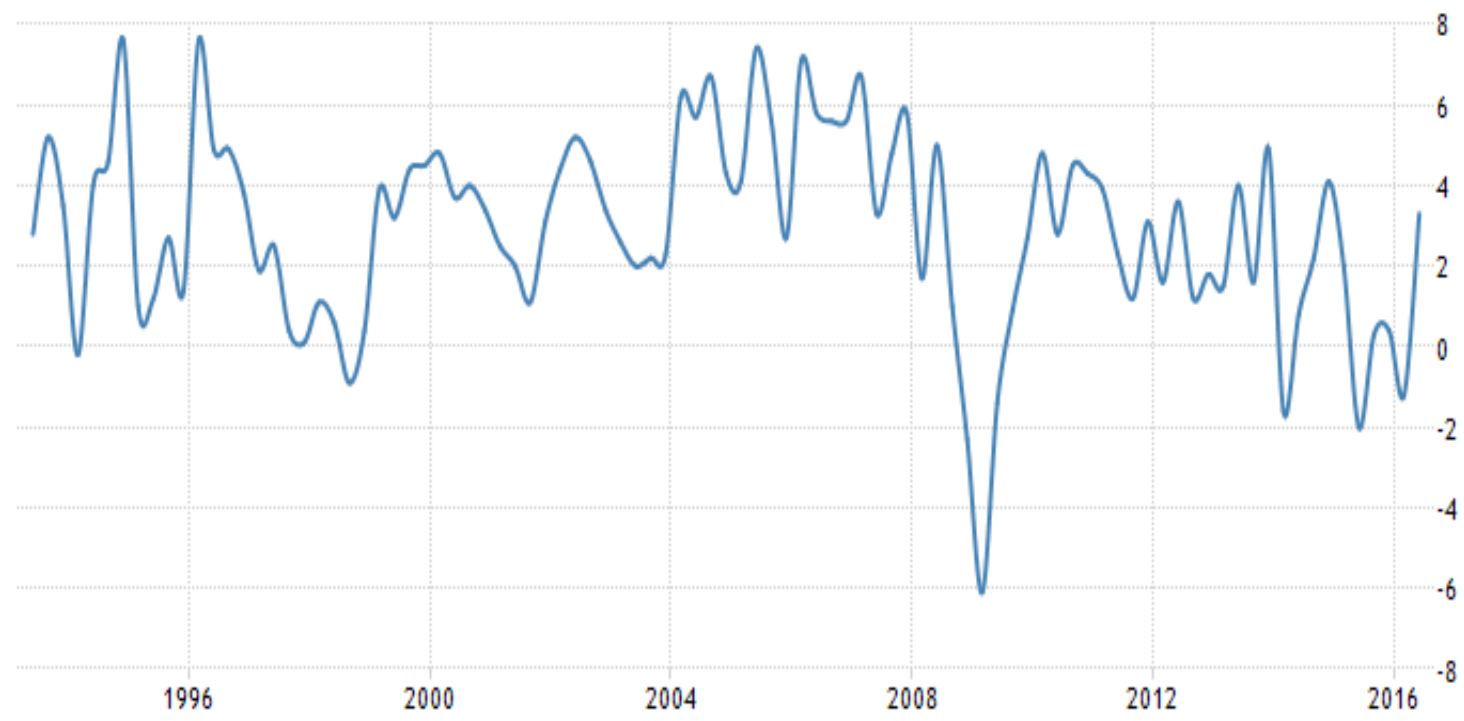

Source: World Bank, 2016.

In South Africa, internal political and economic problems have hindered efforts to improve economic prosperity and sustain development in the country. The relationship between interest rates and FDI is dynamic and differ from country to country (Siddiqui, 2014). South Africa is currently ranked $49^{\text {th }}$ on the "FDI Performance Index" in the Global Competitiveness Report (2015-2016) (WEF, 2015). An increase in the interest rate could increase the cost of money and could possibly "crowd out" domestic demand, especially taking into account that investments are affected by interest rates (Jordaan, 2013). This is a major problem because this will leave the South African economy in a stagnant state and could harm the economy by even decreasing the current growth rate. It is considered that the country has the potential to attract investment with the significant benefits from it (Wentzel \& Steyn, 2014). It should be noted that the country has a number of stumbling blocks that affect FDI such as political instability, infrastructure capacity issues, shortages in highly skilled labour, high levels of crime, exchange controls, restrictive labour regulations and low economic growth (Tuomi, 2009; Lundahl \& Petersson, 2013). FDI and interest rates are important economic indicators in economic growth.

\section{Literature Review}

According to Piana, (2005) FDI can be explained as a financial investment that can eventually lead to the significant influence of the management of the countries interest rate and growth potential. According to the definitions of the IMF (2001) and OECD (1996), FDI has the intention of attaining an interest of a direct investor in a firm in another economy which is known as the direct investment firm. The benefits of FDI for the host country are important and include issues such as technology spillover, human capital formation, improvement of the local business environment, improvement of integration to international trade and advancement of local firm development (Kurtishi-Kastrati, 2013). It can contribute to economic development add to improved foreign exchange, and growth in tax revenue for developing countries (Quazi, 2007). UNCTAD, (2006) found that the effect FDI has on employment is moderate however, it was reported that there is a larger impact in developing countries than that of developed countries, notably in the manufacturing sector. The interest rate is defined as the cost of borrowing or return on savings (Pritchard, 2015). Lower 
rates or low-cost funding source is the aim for investors, and investors will invest in favourable interest rates or favourable returns. It has the result that capital could be attracted to a high rate country to a low rate country (Siddiqui, 2014). Favourable interest rate can lead to increased FDI because it allows for higher returns on investment although the risks could be higher (Singhania \& Gupta, 2011). International trends are thought to affect South Africa's real interest rates (Farrell \& Kahn, 2002). An important variable of FDI inflows is interest rates which conform to inflation, making interest rate a good measure (Singhania \& Gupta, 2011). Final goods can be defined as the goods which are purchased by the end users (South African Reserve Bank, 2016).

According to Callen (2008), GDP could be defined as the total market value of all produced goods and services, within a specific country and over a specific time frame such as a year or quarter. Market GDP means that all transactions are accounted for, that is money is exchanged for the goods or services. Therefore, if a transaction such as a service is not paid for with money, it does not form part of GDP (Gonzalez, 2001). GDP has an important element which is that it shows all the production within the boundaries of the host country and within a time period (South African Reserve Bank, 2016). Finally, the last part of the definition of GDP is that services and goods which are produced within a certain duration normally a year, are included in the GDP calculation (World Heritage Encyclopaedia, 2016). In should be noted that in most cases investors select countries to invest in which are relatively stable with relatively high interest rates (Botha, 2015). The South African Reserve Bank has to make sure that there is price stability by controlling the inflation rate. An appropriate repo rate is determined bi-monthly by the Monetary Policy Committee. Interest rates in South Africa are currently at 6.5 percent (South African Reserve Bank, 2018). Kamath, (2008) argues that economic growth can be accelerated through FDI inflow due to the fact that it could have a constructive effect on exports and has considerably added to GDP.

The goods market and the money market are also linked to investments. Investment fluctuations also drive much of the business cycle (Dornbusch et al., 2011). The Hayekian and Keynesian perspective are analysed as the two ways of thinking about investment. The Hayekian perspective thought of investment as the rate to which equilibrium was adapted and therefore, the speed of adjustment is the decision of the best amount of investment effectively (Chingarande et al., 2012). However, the nature of the investment decision was less emphasized with the Keynesian approach. Investment decisions were more on the behavioural take (Faroh \& Shen, 2015). Microeconomics, macroeconomics, social and political perspectives have many factors that influence the flow of FDI (Siddiqui, 2014). With regards to economic development, FDI is significantly important and most researchers have tested numerous variables to understand the impact on FDI. Yong Ting \& Cheong Tang (2010) composed research in Malaysia and found a positive relationship between investment and infrastructure development and capacity, market size, interest rate, trade openness, exchange rate, level of corruption and inflation.

In India, Singhania and Gupta (2011) found that interest rate and GDP affected FDI. Interest rates adapt for inflation, which is a fair measure and important variable to determine FDI inflows (Singhania \& Gupta, 2011). Investors focus on low-cost funding sources or low rates and will invest in countries or regions with higher returns and relatively higher interest rates. According to Chakrabarti, (2011) a positive relationship exists between FDI and interest rates in India. However, Chingarande et al. (2012) established no significant association between FDI and interest rates in the Zimbabwean economy. In some cases, the size of the market has a positive impact on FDI (Tsen, 2005), with the association between the two variables predicted to be positive (Ewe-Ghee, 2001). Most studies in the literature propose that market size is understood to positively have an influence on FDI (Billington, 1999; Cheng \& Kwan, 2000; Shatz \& Venables, 2000). With regards to a study conducted in South Africa, Mahembe, (2014) found that the neoclassical and the new endogenous economic growth theory all propose that FDI can contribute to GDP growth through indirect and direct impacts. Arvanitis, (2002) found that South Africa attracts less FDI than countries with even lower credit ratings.

\section{Methodology}

A quantitative research approach is used to find the effect of foreign direct investment and interest rates on GDP. This study focuses on an analysis of the relationship between the variables namely FDI, repo rate and 
GDP on both the short and the long-run. Quarterly data employed in this study cover the period from 2000 to 2016. All datasets were obtained from the South African Reserve Bank (SARB). While FDI and GDP are measured in millions of Rand, the repo rate is regarded as the rate at which commercial bank lend money from the central bank in South Arica. To analyse the growth or elasticity and the responsiveness of the dependent variables towards fluctuations in the independent variable, each variable was transformed into a natural logarithm. An ARDL model was utilized to analyse the abovementioned relationships. A Granger causality estimation was also employed to establish the causal relationships amongst variables. The used ARDL econometric model originates by Pesaran et al. (2001). Contrary to the Johansen test of co-integration that requires all variable to be I (1), the ARDL model has the advantage of dealing with variables that are cointegrated of order zero [I (0)], order one [I(1)] or a mixture of the two. Additionally, besides being an efficient model when a small sample size is employed, the econometric model estimates both the long and short-run coefficients simultaneously. Lastly, the use of the ARDL model allows to include a different number of optimal lags in the same model.

This study employed an ARDL model because variables are a mixture of I (0) and I (1). All variables were converted to natural logs. To determine the effects of FDI and repo rate on the South African GDP, the following model was formulated:

$L G D P_{t}=\beta_{0}+\beta_{1} L F D I_{t}+\beta_{2} L R E P O_{t}+u_{t}$

Where LGDP represents the natural log of GDP (at constant prices), LFDIis the log of FDI, LREPO is the natural logartm of the repo rate and $u$ is the error term. Using the ARDL approach, from equation (1), the following equation was formulated:

$L G D P_{t}=\beta_{0}+\sum_{i=1}^{n} \beta_{1 i} L G D P_{t-1}+\sum_{i=1}^{n} \beta_{2 i} L F D I_{t-1}+\sum_{i=1}^{n} \beta_{3 i} L R E P O_{t-1}+\delta_{1} L G D P_{t-1}+\delta_{2} L F D I_{t-1}+$ $\delta_{3} L R E P O_{t-1}+e_{t}$

Where $\beta_{0}$ is the drift component and $e_{t}$ is the white noise residuals. The symbols $\beta_{1}$ to $\beta_{3}$ represent short run changes of the model, whilst $\delta_{1}$ to $\delta_{3}$ are the long run coefficients. The Pesaran et al. (2001) Bounds test procedure is performed to determine the long-run relationship. The Bounds testing procedure determines whether variables are co-integrated or not. The F-testing was used to test the following hypothesis:

$H_{0}: \delta_{1}=\delta_{2}=\delta_{2}=\delta_{3}=0$ (variables are not co-integrated)

$H_{1}: \delta_{1} \neq \delta_{2} \neq \delta_{2} \neq \delta_{3} \neq 0$ (variables are co-integrated)

The Wald-test or F-statistics forms the base of the ARDL Bound test. Pesaran et al. (2001) suggest two critical values for the cointegration tests. The first is the lower critical bound assuming that all variables I(0) and not cointegrated. The second is the upper bound assuming that all variables are I (1) suggesting that they are cointegrated. The $\mathrm{H}_{0}$ is rejected if the calculated F-statistics is greater than the upper bound. However, if the calculated F-statistics falls below the lower bound, the $\mathrm{H}_{0}$ is not rejected meaning that there is no cointegration amongst variables. Pesaran et al. (2001) stated that if investigated variables are co-integrating, it is imperative to develop an unrestricted error correction model (UECM). From equation (2), the error correction was expressed as follow:

$\Delta L G D P_{t}=\beta_{0}+\sum_{i=1}^{n} \beta_{1 i} \Delta L G D P_{t-1}+\sum_{i=1}^{n} \beta_{2 i} \Delta L F D I_{t-1}+\sum_{i=1}^{n} \beta_{3 i} \Delta L R E P O_{t-1}+\varphi E C_{t-1}+u_{t}$

Where $\Delta$ indicates changes, $\varphi$ is the speed of adjustment parameter and the $E C$ is the error correction term derived from the estimated long run (cointegration) model (equation 2).

\section{Results and Discussion}

Unit Root Test: The absence or presence of unit roots within variables is determined by using the units' root test. This test shows whether the data is stationary or non-stationary over time, therefore this procedure is important (Erding, 2010). In most cases, the Augmented Dickey-Fuller (ADF) test is used because of its practical superiority over almost all of the alternative techniques of testing for stationary of time series (Jebb et al., 2015). Table 1, represents all the results of the unit root test for the time series employed in this study. The results show that LFDI is stationary at level or order zero I (0), while GDP and repo rate are stationary 
after being differentiated, thus, they are stationary at I (1). The model that needs to be estimated should therefore be able to handle variables that have a mixture of stationarity.

Table 1: Unit Root Test Results

\begin{tabular}{|c|c|c|c|c|c|c|}
\hline \multirow[t]{2}{*}{ Variable } & \multirow[t]{2}{*}{ Levels } & \multicolumn{5}{|c|}{ First Difference } \\
\hline & & P-value & T-statistic & P-Value & T-Statistic & $\begin{array}{l}\text { integration } \\
\text { order }\end{array}$ \\
\hline \multirow[t]{2}{*}{ LFDI } & Intercept & $0.0000^{* * *}$ & -2.91173 & 0.0000 & 0.0000 & $\mathrm{I}(0)$ \\
\hline & Intercept \&trend & $0.0000^{* * *}$ & -3.487845 & -2.91263 & -3.489228 & $\mathrm{I}(0)$ \\
\hline \multirow[t]{2}{*}{ LGDP } & Intercept & 0.1660 & -2.912631 & $0.0033^{* * *}$ & -2.912631 & $\mathrm{I}(1)$ \\
\hline & Intercept \&trend & 0.9495 & -3.489228 & $0.0026^{* * *}$ & -3.489228 & $\mathrm{I}(1)$ \\
\hline \multirow[t]{2}{*}{ LREPO } & Intercept & 0.0804 & -2.912631 & $0.0099 * * *$ & -2.912631 & $\mathrm{I}(1)$ \\
\hline & Intercept \&trend & 0.1615 & -3.489228 & $0.0349 * *$ & -3.489228 & $\mathrm{I}(1)$ \\
\hline
\end{tabular}

Note: ${ }^{* *},{ }^{* *}$, and ${ }^{*}$ denotes a rejection of null hypothesis $1 \%, 5 \%$ and $10 \%$ level respectively.

Correlation Coefficient Analysis: Correlations are utilized to analyse if a relationship exists between two variables and how the variables fluctuate together (Rouse, 2013). There could be a positive correlation which means that the two variables are moving in the same direction or the variables are decreasing or increasing in parallel. However, a negative correlation between two or more variables shows that as the one variable increases the other variable will decrease (Jebb et al., 2015). The results of the correlation tests are indicated in Table 2. As indicated in Table 2, there is a positive association between LFDI and LGDP, with a significant positive relationship and coefficient of 0.2865 .

Table 2: Correlation between FDI, GDP and Repo Rate

\begin{tabular}{|c|c|c|c|c|}
\hline \multirow{2}{*}{$\begin{array}{l}\text { Probability } \\
\text { LGDP }\end{array}$} & & LGDP & LFDI & LREPO \\
\hline & & 1.0000 & & \\
\hline & P-value & ------- & & \\
\hline \multirow[t]{2}{*}{ LFDI } & & 0.2865 & 1.0000 & \\
\hline & P-value & $0.0264^{* *}$ & --------- & \\
\hline \multirow[t]{2}{*}{ LREPO } & & -0.6944 & -0.1401 & 1.0000 \\
\hline & P-value & $0.0001^{* * *}$ & 0.2855 & --------- \\
\hline
\end{tabular}

Lag Length Selection: The selection of lag length is an important step for time series analysis. The number of lags selected plays a significant role in the value of F-statistic. Thus, insufficient as well as the excess number of lags can lead to spurious regression or wrong conclusion (Bahmani-Oskooee \& Brooks, 1999). Five information criteria are utilized in the determination the optimum number of lags to be integrated into the model. The majority of the criteria (four out of five) suggest the use of two lags. Therefore, for this study only two lags were included.

Table 3: Lag Length Selection Criteria

\begin{tabular}{lllllll}
\hline Lag & Log L & LR & FPE & AIC & SC & HQ \\
\hline 0 & -466.2243 & NA & 62155.76 & 19.55101 & 19.66796 & 19.59521 \\
1 & -258.5863 & 380.6696 & 15.83085 & 11.27443 & $\mathbf{1 1 . 7 4 2 2 3}^{*}$ & 11.45121 \\
2 & -243.4682 & $\mathbf{2 5 . 8 2 6 8 4}$ & $\mathbf{1 2 . 3 3 1 5 3}$ & $\mathbf{1 1 . 0 1 9 5 1 *}$ & 11.83816 & $\mathbf{1 1 . 3 2 8 8 8}^{*}$ \\
3 & -240.6991 & 4.384295 & 16.18479 & 11.27913 & 12.44863 & 11.72109 \\
4 & -232.2677 & 12.29581 & 16.95848 & 11.30282 & 12.82317 & 11.87736 \\
5 & -223.8800 & 11.18358 & 18.06805 & 11.32833 & 13.19954 & 12.03546 \\
6 & -213.2670 & 12.82404 & 17.89794 & 11.26113 & 13.48318 & 12.10084 \\
7 & -208.0599 & 5.641065 & 22.79924 & 11.41916 & 13.99206 & 12.39147 \\
8 & -200.0950 & 7.632987 & 26.80418 & 11.46229 & 14.38605 & 12.56718 \\
\hline
\end{tabular}

* indicates the optimum number of lags selected by each criterion 
The ARDL Bound Testing and Long Run Relationship Analysis: Table 4 reports findings from the ARDL Bounds test for cointegration. The computed F-statistic is greater than all Pasaran et al. (2001) critical values, even at 1 percent level of signified. Consequently, the null hypothesis for no cointegration amongst variables is rejected. In conclusion therefore it is confirmed that for the variables included in the study, a long-run relationship exists.

Table 4: ARDL Bounds Test Results

\begin{tabular}{lll}
\hline Dependent variable LGDP & Estimated F-Statistic 14.6014 & \\
\hline Critical Values* & Lower Bound Critical Value I(0) & Upper Bound Critical Value I(1) \\
$1 \%$ & 5.14 & 6.39 \\
$5 \%$ & 3.78 & 4.87 \\
$10 \%$ & 3.16 & 4.15 \\
\hline
\end{tabular}

Note: * critical values from Pesaran et al. (2001) Table CI (V).

Since it known that a cointegration or long-run relationship exists amongst the variables, it vital to analyse the effect of independent variables on the dependent variables on the long-run. Equation (4), exhibits the equation:

LGDP $=16.5382+0.0780 *$ LFDI $-0.5805^{*}$ LREPO

Considering the result from Equation (4), it can be concluded that a 1 percent increase in FDI leads to only0.08 percent growth in GDP. In addition, a negative long-run relationship exists between GDP and the repo rate. When the repo rate increases by 1 percent, the level of GDP declines by 0.58 percent. This shows that capital inflow from foreign investors supports economic growth whilst the repo rate growth generates negative impacts on economic growth in the domestic economy. Since variables cointegrated, the subsequent step is to calculate the unrestricted error correction mode. With regards to the relationship between LREPO and LGDP, there is a significant but negative association with a coefficient of-0.6944. There is a negative but non-significant relationship between LREPO and LFDI. All of the relationships are further analysed in the rest of the study using more advanced methods.

Error Correction Model (ECM) and Short Run Relationship Analysis: The vector error correction model indicates the speed by which the model reverts back to the equilibrium after an exogenous shock (Ubesie, 2016). The error correction term (ECT) should be negatively signed and significant, thus showing a movement back in the direction of equilibrium. A positive sign implies a move away from equilibrium (Jebb et al., 2015). Table 5 exhibits the result of the error correction model and the short-run findings. In the shortrun, FDI is significant at 10 percent level, meaning a weak significance. If FDI increases by 1 percent, in the short-run, GDP increases by only 0.002 which is almost insignificant. This result makes sense, since it takes time for the investment to impact on the country's economy. Contrary to the FDI, the repo rate is strongly significant and positive. This indicates that, in the short-run, a linear relationship exists between the repo rate and GDP. When the repo rate increases by 1 percent, GDP declines by 0.05 percent. With regards to the error correction model, it was found that the error term (ECT) is negative and significant as expected. The error term of -0.019330 , suggests that approximately 0.2 percent of chocks in the model is correct each quarter. Thus, it takes more than 51 quarters $(1 / 0.019330)$ for the model to come back to the equilibrium.

Table 5: Short run and Error Correction Model (ECM)

\begin{tabular}{lllll}
\hline Variable & Coefficient & Std. Error & t-Statistic & Prob. \\
\hline D(LGDP(-1)) & -0.216145 & 0.143176 & -1.509642 & 0.1372 \\
D(LFDI) & 0.001823 & 0.000977 & 1.865801 & $0.0677^{*}$ \\
D(LREPO) & 0.054991 & 0.019299 & 2.849451 & $0.0063^{* * *}$ \\
CointEq(-1) & -0.019330 & 0.002455 & -7.873328 & $0.0000^{* * *}$ \\
\hline
\end{tabular}

Note: ${ }^{* *},{ }^{* *}$, and ${ }^{*}$ denotes a rejection of null hypothesis $1 \%, 5 \%$ and $10 \%$ level respectively.

PairWise Granger Causality Analysis: Granger causality test is used to predict short-run changes in one variable $(\mathrm{X})$ as a result in the other variable $(\mathrm{Y})$ changes. As illustrated in Table 6 , there is only one-way relationship between repo rate and GDP. Changes in GDP can influence the level of repo rate yet the later does 
not have an effect on short-term changes in GDP. Although a long-run relationship exists between GDP and FDI as displayed in Table 4, there is no causality between these two variables.

Table 6: Granger Causality Tests

\begin{tabular}{lllll}
\hline Null Hypothesis: & F-Statistic & Probability & Causality & $\begin{array}{c}\text { Direction of } \\
\text { causality }\end{array}$ \\
\hline FDI does not Granger Cause LGDP & 0.2638 & 0.7691 & No & \\
LGDP does not Granger Cause FDI & 2.0142 & 0.1435 & No \\
LREPO does not Granger Cause LGDP & 2.1933 & 0.1216 & No \\
LGDP does not Granger Cause LREPO & 7.3794 & $0.0015^{*}$ & Yes at 5\% \\
\hline
\end{tabular}

Note: ${ }^{*}$ denotes a rejection of null hypothesis at $1 \%$ level.

The effectiveness and reliability of the model are defined by the diagnostic tests results. The results indicate that the model passed the normality, serial correlation and heteroscedasticity tests. All P-values are greater than the alpha of 5 percent. Therefore, findings from the model are accurate and reliable.

Table 7: Diagnostic checking

\begin{tabular}{llll}
\hline & Test & P-value & Conclusion \\
\hline Normality & JB & 0.7507 & Data is normally distributed \\
Serial Correlation & LM & 0.1775 & No serial correlation \\
Heteroscedasticity & White & 0.2675 & No Heteroscedasticity \\
\hline
\end{tabular}

\section{Conclusion and Recommendations}

The aim of the study was to determine the relationship between FDI, GDP and Repo rate in South Africa. The analysis focussed on correlation, causality long and short-run relationships. Findings of this study revealed that DFI and GDP are positively correlated while GDP and repo rate are negatively correlated. This preliminary analysis was supported by the long run relationships analysis. The increase of FDI leads to the economic growth in the country. This positive effect of FDI towards long-run economic growth was also found for short-run relationship analysis, yet the effect is very minimal. Despite a negative relationship between GDP and repo rate, in the short run the repo rate positively affect the level of GDP. The Granger causality results, suggested only a unidirectional relationship between GDP and repo rate. Therefore, GDP can be a short-run predictor of repo rate but not vice versa. The trustworthy of findings are supported by the diagnostic tests. The diagnostic tests indicated that the stable. In terms of policy suggestion or recommendations, the South African macroeconomists and policymakers should mostly focus on creating opportunities that attract foreign investors in order to improve the country's economy. On the other hand, while implementing interest rate policies should consider its long-run effect on economic growth.

\section{References}

Arvanitis, A. (2002). Foreign Direct Investment in South Africa: Why has it been so low? https://www.imf.org/external/pubs/nft/2006/soafrica/eng/pasoafr/sach5.pdf. Date of Access: 20 October 2017.

ATKearney (2017). FDI Confidence Index. https://www.atkearney.com.au/paper//asset_publisher/dVxv4Hz2h8bS/content/the-2017-foreign-direct-investment-confidence-index/. Date of access: 15 June 2018.

Bahmani-Oskooee, M. \& Brooks, T. J. (1999). Bilateral J-curve between US and her trading partners. Welt wirtscha ftliches Archive, 135(1), 156-165.

Billington, N. (1999). The location of foreign direct investment: An empirical analysis. Applied Economics, 31(1), 65-78.

Botha, R. (2015). Bad timing for interest rate hike. Web Access. www.moneyweb.co.za/moneywebopinion/bad-timing-for-interest-rate-hike/. Date of Access: 2 March 2018. 
Callen, T. (2008). What is GDP? https://www.imf.org/external/pubs/ft/fandd/2008/12/pdf/basics.pdf Date of Access: 22 August 2017.

Chakrabarti, A. (2003). A theory of the special distribution of foreign direct investment. International Review of Economics \& Finance, 12(1), 149-169.

Chakrabarti, A. (2011). The determinants of foreign direct investments: Sensitivity analyses of cross-country regressions. Kyklos, 1(2), 89-114.

Cheng, L. K. \& Kwan, Y. K. (2000). What are the determinants of the location of foreign direct investment? Journal of International Economics, 51(2), 379-400.

Chingarande, A., Webster, D. \& Karambakuwa, R. T. (2012). The impact of interest rates on FDI: a case study of Zimbabwean economy. International Journal of Management Sciences and Business Research, 1(5), 2229.

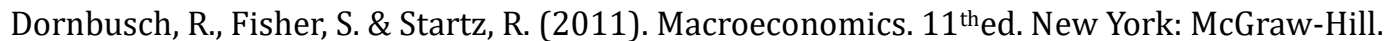

Erding, A. (2010). Time Series. http://home.aubg.edu/faculty/didar/EC0\%20310/TimeSeries.pdf. Date of Access: 8 November 2017.

Ewe-Ghee, L. (2001). Determinants of and the relation between foreign direct investment and Growth: A summary of the recent literature. International Monetary Fund Working Paper, WP/01/175.

Faroh, A. \& Shen, H. (2015). Impact of interest rates on FDI: case study of Sierra Leone economy. International Journal of Business Management and Economic Research, 6(1), 124-132.

Farrell, G. N. \& Kahn, B. (2002). South African real interest rates in comparative perspective: theory and evidence. South African Reserve Bank, 17(1), 1-6.

Gonzalez, F. (2001). Introduction to Macroeconomics and GDP definitions. http://www.shsu.edu/fxg001/Principle_of_Macroeconomics_files/Lecture1_intromacroandgdp.pdf Date of Access: 22 August 2017.

Harmse, C. (2006). The relationship between South Africa's macroeconomic policies and the performance of the various asset classes. www.resbank.co.za/Lists/News\%20and\%20Publications/Harmse.pdf. Date of Access: 29 April 2018.

Hogg, A. (2016). Why economic growth really, really matters. www.fin24.com/BizNews/why-economicgrowth-really-really-matters-20160308. Date of Access: 2 March 2018.

IMF (International Monetary Fund). (2001). Balance of Payments Statistics Yearbook. Washington DC.

Jebb, A. T., Tay, L., Wang, W. \& Huang, Q. (2015). Time series analysis for psychological and forecasting change. http://journal.frontiersin.org/article. Date of Access: 20 October 2017.

Jordaan, J. C. (2013). Impact of interest rate changes on South African GDP and households: a combine macroeconomic and social accounting matrix modelling approach. Southern African Business Review, $17(3), 158-160$.

Kamath, G. B. (2008). Impact of Foreign Direct Investment in India. ICFAI University Journal of International Business, 3(4), 35-38.

Kurtishi-Kastrati, S. (2013). The effects of Foreign Direct Investment for host country's economy. American University of the Middle East, 5(1), 26-29.

Lings, K. (2017). SA economy is stuck. https://www.moneyweb.co.za/news/economy/sa-economy-is-stuck/. Date of access: 15 May 2018.

Lundahl, M. \& Petersson, L. (2013). Post-apartheid South Africa: an economic success story? Achieving development success: Strategies and lessons from the developing world, 232.

Mahembe, E. (2014). Foreign direct investment inflows and economic growth in SADC countries. http://uir.unisa.ac.za/bitstream/handle/10500/14232/dissertation_mahember_e.pdf?sequence=1 Date of Access: 20 October 2017.

OECD (Organisation for Economic Cooperation and Development). (1996). Benchmark Definition of Foreign Direct Investment. $3^{\text {rd }}$ edition. Paris.

Pesaran, M. H., Shin, Y. \& Smith, R. J. (2001). Bounds testing approaches to the analysis of level relationships. Journal of Applied Econometrics, 16(3), 289-326.

Piana, V. (2005). Foreign Direct Investment. http://www.economicswebinstitute.org/fdi.htm. Date of access: 22 August 2017.

Pritchard, J. (2015). What is the interest rate on loans or savings? https://www.thebalance.com/what-is-theinterest-rate-on-loans-or-savings-315437.

Quazi, R. M. (2007). Investment climate and Foreign Direct Investment: A study of selected countries in Latin America. Global Journal of Business Research, 1 (2), 1-13. 
Rouse, M. (2013). Correlation. http://whatis.techtarget.com/definition/correlation. Date of access: 8 November 2017.

Samuel, C. (2013). The dark side of Foreign Direct Investment: A South African perspective. South African Institute of International Affair, 167(1), 5-7.

Shatz, H. J. \& Venables, A. J. (2000). The geography of International investment. The Oxford Handbook of Economic Geography, 1(2), 125-145.

Siddiqui, H. A. A. (2014). Role of interest rate in attracting the FDI: Study on ASEAN 5 economy. International Journal of Technical Research and Applications, 2(3), 59-70.

Singhania, M. \& Gupta, A. (2011). Determinants of foreign direct investment in India. Journal of International Trade Law and Policy, 10(1), 64-82.

South African Reserve Bank. (2016). Current market rates-interest rates. /www.resbank.co.za/Research/Rates/Pages/CurrentMarketRates.aspx. Date of access: 2 March 2018.

South African Reserve Bank. (2016). Gross Domestic Product. http://www2.resbank.co.za/internet/Glossary.nsf/0/08eac6efc196014642256b43002e76dc?0penDo cument. Date of access: 2 October 2017.

South African Reserve Bank. (2018). Statement by Monetary Policy Committee. https://www.resbank.co.za/Lists/News\%20and\%20Publications/Attachments/8466/MPC\%20Statem ent\%20May\%202018.pdf. Date of access: 30 May 2018.

Stats SA. (2018). Gross Domestic Product (GDP), First quarter 2018, Statistical release no P0441. statssa.gov.za/publications/P0441/P04411stQuarter2018.pdf. Date of access: 20 July 2018.

Tsen, W. H. (2005). The determinant of foreign direct investment in the manufacturing industry of Malaysia. Journal of Economic Cooperation, 26(2), 91-110.

Tuomi, K. L. (2009). Fundamentals, Tax incentives and foreign direct investment. PhD thesis, American University, Washington DC.

Ubesie, M. (2016). The Effect of Financial Sector Liberalization on Economic Growth in Nigeria. International Journal of Finance and Accounting, 5(4), 193-201.

UNCTAD. (2006). World Investment Report 2006: FDI from developing and Transition Economies: Implications for development. Geneva: United Nations.

Wentzel, M. S. I. \& Steyn, M. (2014). Investment promotion in the South African manufacturing industry: incentive comparisons with Malaysia and Singapore. South African Journal of Economic and Management Sciences, 17(3), 6-9.

World Bank. (2016). South Africa Economic Update: Promoting domestic competition between firms could help spur growth, reduce poverty.

World Economic Forum. (2015). Competitiveness Ranking. www.reports.weforum.org/globalcompetitiveness-report-2015-2016/competitiveness-rankings. Date of access: 2 March 2018.

World Heritage Encyclopaedia. (2016). GDP. http://www.worldlibrary.org/articles/gdp. Date of access: 2 October 2017.

Yong Ting, A. \& Cheong Tang, T. (2010). The determinants of inward foreign direct investment: The case of Malaysia. International Journal of Business \& Society, 1(1), 59-76. 